\title{
Recent Skirmishes in the Battle Over Corporate Voting and Governance
}

\author{
Brett H. McDonnell
}

\section{Introduction}

\section{Conceptual framework-Our mixed federal system}

I will place the developments of the last few years within a general framework describing and analyzing our federal system for making corporate law. The core of corporate law in the U.S. is set at the state level by state legislatures and courts. Corporations can choose which state's law they prefer to govern them by choosing in which state to incorporate. A favorite topic of debate among corporate law scholars has long been whether this system leads to a race to the bottom, to the top, or somewhere in between, if indeed there is any race at all.

Recently, a variety of scholars have pointed out that much corporate law is really set at the national level, in the guise of securities law. Mark Roe has also emphasized that the threat of federal action conditions what the Delaware legislatures and courts can and will do. The details of how such a mixed federal system work, and whether or not it is likely to lead to good outcomes, remain quite open questions. I have addressed those questions in recent work, and that work provides the framework within which I will address recent developments.

We want to compare the tendencies of three systems: a purely state-based system with a dominant jurisdiction, a purely national system where only the federal government dictates corporate law, and our mixed federal system, where states set the basic law but the federal government can and does step in to set rules in a variety of areas. Let us first compare the relative strengths and weaknesses and the state and national systems.

For a variety of reasons, the state system leads to a dominant jurisdiction, Delaware, which sets high quality law. The existence of fifty different states creates a chance for experimentation to discover what works and what does not. Delaware's success, and the resulting large revenue and interested groups like the corporate bar, gives it strong incentive to commit to continuing to be responsive to corporate needs. Delaware courts and judges are fast and knowledgeable. Its common law system allows both flexibility and a fair degree of predictability and guidance, and Delaware's ongoing dominance provides assurance that Delaware law will continue to adapt to new circumstances with new case law.

A purely national system could re-create some of these advantages, such as an experienced and knowledgeable rulemaking body like the SEC. However, important elements of Delaware's advantage would not replicate absent the competition it faces. The ultimate rulemaking body in a national system, Congress, is likely to be far less 
knowledgeable and interested in corporate law than the Delaware legislature. The SEC will be more knowledgeable, but its lack of competition will give it less incentive to respond quickly to changes or to evidence of problems in its rules. Moreover, the impulse to over-doing regulation as a way to expand bureaucratic turf will not be tempered by the threat of losing corporate subjects to competitors, as is the case with the Delaware courts. Thus, the state system is likely to lead to higher quality law than a national system.

However, this quality comes at a price. Delaware is likely to be more biased in the interests of corporate directors and officers, and to ignore the interests of nonshareholder constituencies such as creditors, employees, and customers. Corporate managers are likely to be the best-organized constituency group interested in how corporate law is set, and they play the leading role in determining in which states corporations will incorporate. The strong Delaware corporate bar will largely, although not perfectly, reflect the interests of managers. Consequently, Delaware legislators and judges will be particularly attentive to managerial interests. Although some degree of managerialist bias may exist at the national level as well, it is likely to be weaker than what we observe in Delaware.

We thus face a tradeoff in comparing the state and national systems: the state system tends to lead to higher quality law, but it is also more biased in favor of managers and against other non-shareholder constituencies. Assuming that we care about both quality and achieving a desirable balance between interest groups, which of these two systems is better depends on exactly how much the two differ in these two dimensions and on how our social preferences (whatever metric we are using to evaluate the law and its effects) trade off quality and bias.

Might a mixed federal system achieve a better tradeoff? In a wide range of circumstances, yes. Consider how such a system works. As Roe has emphasized, Delaware (and other states) may act first in setting corporate law, but it is subject to the risk of federal preemption if it sets a law that the national decisionmakers do not like. Roe does not really spot the possible gains from this system, though, because he essentially conceives corporate rulemaking as a pure struggle between interest groups, and he does not focus on the quality dimension of corporate laws. Once we add this dimension to the analysis, the following possibility occurs. If Delaware's preferred outcome, what it would do in a purely state-based system, lies too far in a managerialist direction, then it faces action from Congress or the SEC if it sets the law there. The federal actors will be willing to overturn Delaware's law despite the general high quality of that law. Facing this threat, Delaware will choose to curb its managerial bias enough so that it will not be preempted.

The result is Delaware quality with less of the Delaware bias than in the state system. The Delaware bias will not disappear, for several reasons. First, for various reasons governmental institutions face inertia in rulemaking, and so even if the law is somewhat more biased than the federal rulemakers like they may not intervene. Second, insofar as the federal rulemakers do want to achieve high quality law, they will allow 
Delaware law that is better than they can achieve to stand even if it is somewhat more pro-manager than they would like. Still, the Delaware bias will often be reduced from the state-only system.

I show elsewhere that under many circumstances this result is better than either the state or the national system - not perfect, but better. Indeed, if we assume that social preferences coincide with the preferences of the national actors, this must be true- the national actors can always intervene if they want, so if they do not the result must be at least as good as they can achieve on their own, and insofar as the threat of intervention has made Delaware less biased than it would be on its own without sacrificing quality, that is a clear improvement.

However, the mixed federal system is not better than both alternatives under all circumstances. Sometimes the state system may be better. This may happen if the federal lawmakers are too anti-manager in their approach, if the federal lawmakers intervene too much as a way of increasing their own influence, or if the federal lawmakers just intervene mistakenly too often. However, even then the mixed system is better than a purely national system - at least it retains some of the advantages of the state system.

Other times the national system may do better than the mixed federal system. This may happen if even the federal lawmakers are overly-biased in favor of managers, even though less biased than Delaware. In that case, the federal lawmakers may tolerate Delaware rules that are socially worse than what the federal lawmakers could do on their own, because federal lawmakers are willing to trade off more bias for quality than is socially optimal. Still, even then the mixed system is better than a purely state systemat least it curbs Delaware somewhat, though not enough.

Thus, the framework suggests three possible situations: the mixed federal system improves upon both the state and the national system; the mixed federal system is not as good as the state system but better than the national system; or the mixed federal system is not as good as the national system but better than the state system. In which of these three possible worlds do we live? That is the question that the rest of this essay will explore, using the framework to shed light on recent developments and using recent developments to help determine which of these three possibilities appears to be the most plausible description of reality.

Part III presents the case that the mixed federal system has responded to the recent corporate scandals better than either a state or national system would have. SarbanesOxley and other national responses moved the law in a less managerialist direction than the states on their own would have achieved, and also helped push the more expert decisionmakers to step in and make less biased law. Part IV considers the case for believing that a pure state system would have done better. The core claim here is that Sarbanes-Oxley has been an expensive failure. I survey the evidence so far and suggest that although this is a possibility, the full evidence so far does not by any means compel such a conclusion, and indeed it seems implausible. More likely, it has been an 
expensive mixed bag. Part V considers the case for believing that a pure national system would have done better. Though less trendy, I find this claim more plausible than the opposite. An overly pro-manager bias may well pervade governmental decisionmakers at all levels, and the national lawmakers may therefore be acceding to a biased state system that is worse than what they would do on their own. In particular, recent battles over the rules governing shareholder voting and proxy access suggest that managers have re-took political ground that they appeared to have given up in the first few years after the scandals. However, as of this writing the battle continues, and it is not easy to see how it will end.

\section{The case for our federal system: Muddling ahead}

It is quite hard to determine how high is the quality of a system of corporate law and how far it has gone in favoring the interest of managers over other constituencies. Still, at a broad level a variety of pieces of evidence suggest that as of 2000 the American system of corporate regulation had gone rather too far in the direction of favoring managers. The major scandals that would soon erupt at companies like Enron, WorldCom, Tyco, and so on were the tip of the iceberg. Lower scale fraud-like behavior in the form of things such as earnings management, or laddering in IPOs, appears to have been widespread. Executive compensation exploded, apparently beyond what any reasonable form of performance-based rewards would allow. Hostile takeovers, with their potential to discipline bad managers, had virtually disappeared, but ill-considered acquisitions that subsequently appear to have been bad news for the shareholders of the acquirers flourished.

Developments in Delaware helped explain some of this managerial recklessness. The Unocal standard for reviewing antitakeover measures had become mostly toothless. The Revlon standard for reviewing sales of control had some more bite, but its range of application had been narrowed significantly. Case law setting the pleading standard for derivative causes of action had made it hard for plaintiffs to survive a motion to dismiss. For a moment in the mid-eighties the Delaware courts had appeared to take the duty of care seriously, but the legislature had quickly moved to allow corporations to circumvent director liability for care violations, and most companies took advantage of that escape clause. Even the tougher loyalty standard of review had loosened over the years.

Into this atmosphere came the collapse of the dotcom stocks and a spate of serious corporate scandals. There was a cry for a regulatory response to the problems, and the leading response came at the national level. In 2002 Congress passed the Sarbanes-Oxley Act. SOX changed corporate law in a variety of ways. It strengthened requirements for internal control procedures, mandating that CEOs and CFOs must certify a variety of points concerning their controls and outside audits must opine on the controls as well; it created a new, more independent body to regulate the accounting industry; it limited the ability of auditors to provide other services to audit clients; and it added new requirements for independent audit committees, among its most important elements. 
Does SOX fit the relatively optimistic version of federal intervention sketched in the previous section? On the dimension of favoring competing constituency groups, it certainly does seem like a clear move against the interests of directors and officers, as the theory predicts. This fits the general historical pattern of federal intervention in corporate governance rules. However, many have claimed that SOX intervened in clumsy, heavyhanded, and poorly targeted ways. Note that at least up to a certain point, that too fits our theory-Congressional rulemaking should in general lead to lower quality law than Delaware rulemaking. However, if Congress messed up too badly, it could be that we would have been better off with no intervention at all. In the next section I will consider the case for believing that this is what happened, including a quick look at the existing empirical evidence on the net benefits of SOX. I will argue that current evidence does not strongly point to SOX having costs that clearly outweigh its benefits, although the evidence does not strongly point in the opposite direction either.

For the previous section's story on the benefits of federal intervention to work, though, we should see other sorts of response beyond that of Congress. In particular, we should see Delaware responding with new, rather less pro-manager rules. Several major cases in 2003 did indeed seem to move in that direction. Most importantly, the Chancery Court's decision in the Disney case in that year suggested a new, strengthened duty of good faith which might have some bite in executive compensation and other areas where the duty of loyalty does not apply and the duty of care provides too little in the way of limits. In the Oracle case the court seems to have toughened the standard for reviewing the independence of directors, at least in the context of reviewing the decisions of special litigation committees. In Omnicare the court was unusually tough in reviewing deal protection measures in an acquisition. None of these cases announced significantly new doctrines, but they all applied existing rules in tough, interesting ways which, if extended, could lead to a significant expansion of judicial oversight while retaining the careful, fact-specific, knowledgeable approach for which Delaware judges are known.

More recently, the Delaware legislature also got into the act, albeit in a modest way. It amended the General Corporation Law to make it easier for shareholders to enact bylaws specifying that directors must be elected by a majority vote. Under the amendment, boards would not be able to amend such a shareholder-passed bylaw, a legal question that remains opens for all other forms of shareholder bylaws. In section V I shall look in a bit more detail at the developments in the area of shareholder voting, of which this is just one part.

Also notable is action by other more expert regulators in the shadow of SOX. The New York Stock Exchange and Nasdaq passed a range of rules that created, for listed companies, requirements for three sets of committees of independent directors, the audit, nominating, and compensation committees. The SEC was also active in the years after SOX. In part this was in passing a wide range of regulations implementing the Act. Of more interest was a proposal that if passed would allow shareholders, under certain circumstances, to use the company proxy to nominate candidates for the board. This could significantly expand shareholder power, and may well be a better way of addressing problems in corporate governance than most or all of SOX. 
Alas, these developments have led to pushback, some of which will be the topic of section V. More recent cases seem to have pulled back from the 2003 trio. The SEC too has pulled back. The shareholder proxy access proposal has died. However, the federal courts have stepped in. Shareholder activists attempted to use Rule 14a-8 to put on the ballot a bylaw that would give shareholders the right to use the company proxy to nominate director candidates, thus achieving in their company much the same result that the proxy access proposal required. The SEC, in a no-action letter, allowed the company to exclude this proposal because it relates to an election. This has been the SEC's usual position on such bylaws for at least fifteen years, although earlier it did not interpret its rule in this way, and briefly in 2004 the SEC's staff flirted with allowing such shareholder proposals. Concern for managerial interests seems to have held back the Commission on this one. However, the more politically-insulated federal courts, in this case the Second Circuit, disagreed with the SEC, and ruled that shareholders had the right to have their proposal included in the company proxy material.

Both the pullback of the more politically-attuned Delaware courts and the SEC, and the greater receptiveness to shareholder activism of the federal courts, fit our framework. The move back to a more pro-manager position of the specialists follows a political backlash against SOX that appears to make further pro-shareholder reform less likely, and which may lead to significant pruning of SOX. For now, then, Delaware would seem to have less to fear from further Congressional intervention than was the case in 2003. Less sensitive to political pressure in this area, the federal courts are the actor left willing to push on in advancing shareholder interests. Still, the possibility definitely exists that Congress and the SEC were ultimately too reluctant to enact pro-shareholder reforms and too willing to defer to Delaware's scheme limiting the influence of shareholders. We shall explore this possibility further in section V.

\section{The case for Delaware: Is SOX a costly flop?}

A number of corporate law scholars and others have argued that SOX is a costly flop. Among corporate scholars, leading advocates of this position are Roberta Romano, Larry Ribstein, and Stephen Bainbridge. They argue that it is an unwise federalization of corporate law whose costs have greatly outweighed its benefits. This misbegotten attempt at regulation occurred as Congress panicked in the wake of the Enron and WorldCom scandals with a closely-fought midterm election looming. Much political pressure has built to roll back the most controversial elements of SOX, especially section 404, which requires an outside auditor to certify companies' internal controls. A certain degree of Congressional incompetence is not inconsistent with our story of the superiority of the federal system; indeed, it is very much a part of that account. However, has Congress gone too far in its intervention, either because it is overly beholden to nonmanagerial constituency groups, it is too prone to regulate because of the benefits to legislators that come from action, or out of sheer ignorance? Let us consider the evidence for such a claim. 
Probably the best evidence for the net effects of SOX is its effect on stock prices. If one believes in the efficient market hypothesis, then share prices should reflect the best guess available as to the likely effects on the value of corporations. Of course, it is hard to do such empirical work-since all companies within given categories had to follow the rules, it is hard to separate out the effects of SOX from other things going on at the same time. It is also hard to figure out when information about SOX was reflected in stock prices. Moreover, event studies can at best tell us what shareholders predicted the effects of the Act would be- they could have been wrong.

Still, event studies of the effect of SOX on share prices is the first place to look for an economics-minded scholar interested in analyzing the effects of SOX. Somewhat oddly, Romano does not really systematically do so in her lengthy anti-SOX diatribe. Ribstein does, though, in his look at SOX after three years. He surveys seven such studies. He summarizes these as saying "The results of these studies have been mixed, but the studies tend to indicate that the market has reacted negatively to the adoption and implementation of SOX." This is slightly odd, as four of the seven studies tend to show a positive effect, one no effect, one indeterminate effects, and just one shows a significant negative effect. Ribstein accomplishes this odd summary by focusing on whatever negative evidence each study contains, disparaging the methodology of studies finding a positive effect, and lauding the one study that finds a large negative effect. Thus, the best type of evidence available on the effects of SOX does not systematically support the case against the Act; if anything, the evidence mildly supports the Act.

Another strategy is to consider empirical evidence as to the likely effect of various sections of SOX. The section that has received the most negative popular attention is the internal control provisions of sections 302 and 404 . Here there do seem to be rather high costs, driven in good part by outside auditors who have interpreted the provisions as requiring quite extensive new control procedures-at much profit to the auditors. The most-cited evidence on the direct costs of these controls is a survey by Financial Executives International, which shows costs of close to $\$ 3$ million for large companies. However, this is a survey of the CFOs, by the CFOs, and for the CFOs; its figures should be treated with extreme caution. Romano considers two studies on these rules, which reach conflicting results. From these results Romano manages to conclude that the certification regime should be made optional. Why indeterminate results support a conclusion that the regime should be significantly weakened is not quite clear.

Romano considers evidence as to three other provisions: the independent audit committee requirement of section 301, the auditor conflict rules of section 201, and the prohibition on executive loans of section 402. It is hard to find supporters of the loan ban, and I will not dispute that scholarly consensus. As to the other two provisions though, Donald Langevoort, a leading scholar of the relationship between auditing and corporate governance, has recently considered the evidence and Romano's arguments and shown that, although Romano's position is defensible, there is also plenty of evidence suggesting that the SOX auditing provisions were either harmless or positively beneficial. 
Bainbridge has focused on the provision affecting the regulation of lawyers, section 307. He makes a pretty persuasive case that lawyers have strong enough incentives to not rat on the officers they work for that this provision will not have much effect. Maybe so, but he produces no real empirical evidence for his claims, nor does he make much of a case for concluding that the provision has proven all that costly, either.

Another complaint about SOX is that it is an incoherent hodgepodge of many different provisions. Clearly, not everything makes sense or hangs together well. However, the main thrust of the Act is to focus on a variety of important gatekeepers: independent directors, auditors, lawyers, investment bankers, securities analysts, even employees. The Act tries a variety of ways to give those actors incentives to monitor more closely what is going on within their clients and to disclose problems that they find. It also tries to give some more tools to these gatekeepers to keep informed. This is a coherent strategy, and one that is very much in keeping with the way American corporate governance has been evolving over the last few decades.

We also should not consider SOX in isolation. The Act's opponents argue that even without the Act, state regulators and markets would have replied adequately and with less cost to the scandals. Perhaps, but our theory in sections II and III suggests the contrary. Indeed, the regulatory responses from Delaware, the exchanges, and the SEC may well have been spurred and strengthened by the looming threat of Congressional intervention.

A recurring theme of the SOX opponents has been that the political history of the Act shows a populist panic. Politicians reacted too quickly and without seriously considering the accumulated evidence against the reforms in the Act. However, one can paint a quite different picture of how SOX came into being. Clearly, it was a quick reaction to the Enron and WorldCom scandals. This does seem to reflect a form of availability bias - the recent news focused popular attention in an unusual way, and many people and politicians were not well-informed about the issues of corporate governance.

However, there is a bright side to this. Normally, the politics of corporate governance are subject to capture by motivated interest groups, with corporate managers and the lawyers who serve them as the most important players. This leads to a managerialist bias at both the state and national levels, though it is strongest in Delaware. The popular attention brought on by the scandals represents a relatively rare chance to circumvent this political bias. Even if not as well-informed as one would like, such populist moments might well represent the public interest more accurately than the normal politics of corporate law.

Moreover, it is not at all clear that most of the provisions of SOX were really so poorly informed as the critics maintain. As Romano herself stresses, most of the provisions represented reforms that had been on offer for many years. Many provisions codified either best practices or rules that the exchanges had already adopted, or tweaked existing rules in relatively modest ways. Thus, Congress largely drew upon ideas that had been around for a while, had received a lot of debate, and had been tried out in many 
companies. That is precisely what we would likely a relatively uninformed regulator like the Congress to do. Romano portrays the policy entrepreneurs who suggested many of the Act's provisions, people like Arthur Leavitt, Richard Breeden, Roderick Hills, and Lynn Turner, in an unflattering light. Yet, these are experienced former top regulators at the SEC now free from the press of interest groups - I find it rather hard to find a much better group of people for Congress to look to for ideas.

Thus, the arguments and evidence so far marshaled against SOX is not overwhelming, to say the least. That is not to say that the evidence in its favor are overwhelming either. The evidence is deeply mixed. Yet, I get the sense that a perception is growing that the Act's costs outweigh its benefits. Why is this? I think we need to look to who is leading the anti-SOX charge. There are two main groups. One is corporate officers and directors, the main targets of the regulation. Their motivation is clear, and they have more relevant information concerning the Act's functioning than anyone else. Thus, they are able to manipulate public perception rather effectively. The FEI survey discussed above is a leading example. The other main group is corporate law scholars. These are not a homogenous group, by any means. However, the dominance of a particular brand of pro-market economic reasoning within corporate law scholarship is having a big effect on the reception of SOX. To those familiar with the prior work of Romano, Ribstein, and Bainbridge, it should come as no surprise whatsoever that they paint a negative picture. They are strongly pre-disposed to believe that most efforts at mandatory corporate regulation are bad, and when confronted with mixed evidence it is no surprise that they focus on the negative news and do little to update their prior beliefs.

For those not strongly inclined to believe that an Act like SOX is doomed to fail, I do not think the existing evidence shows clearly that its costs outweigh its benefits. The costs of a few provisions, especially section 404, have been greater than expected, and some provisions, such as the loan ban, are pretty clearly not good ideas. However, these flaws do not necessarily doom the whole Act to being deemed a failure. Moreover, it is worth emphasizing again that much of SOX does represent an attempt to more closely regulate officers and directors - the direction of national regulation suggested as predictable and appropriate by our basic theory. To someone inclined to have an open mind to the evidence here, the question as to the net benefits of SOX remains quite open.

\section{V. $\quad$ The case for nationalization: Are we too easy on managers?}

In general, the mixed federal system seems more likely to go wrong in the opposite direction from that considered in the previous direction. Rather than intervening too much, Congress and other national regulators would, if anything, seem prone to intervene too little. That is because it seems likely that while managers and corporate lawyer will have a less decisive influence in Congress than in Delaware, the basic Olsonian logic of collective action suggests that at all levels, including the national level, managers and corporate lawyers will be better organized than those opposing them, and so even national regulation is prone to tilt in a managerialist direction. Where that is so, our basic theory suggests that Congress may let Delaware law stand even in cases where Congressional intervention, even if of lower quality, would be best for the public interest. 
Developments over the last several years provide a fair amount of evidence for this view. It seems that after the high water mark of SOX, public interest in corporate governance has waned, and the threat of further Congressional action has receded. As this has happened, the normal pattern of managerial dominance of the politics of corporate governance has re-asserted itself at both the state and federal law. One area where this pattern appears is Delaware case law. As discussed in section III, in 2003 a variety of Delaware cases moved towards closer scrutiny of director actions. Since then, the Delaware courts seem to have fallen back to their more usual deference.

In both a recent article and the In Re Toys " $R$ ” Us, Inc. Shareholder Litig. case, Vice-Chancellor Strine advocates an approach to deal-protection measures that gives boards more room to agree to such measures than Omnicare suggests. In the Martha Stewart litigation, the court seemed to cut back on the closer scrutiny of director independence that Oracle opened up. Perhaps most significantly, both the Chancery Court and Supreme Court decisions in the Disney case after trial showed less sympathy to the plaintiffs than the 2003 Chancery decision.

Still, we should not go too far in concluding that Delaware has returned to its old ways. Omnicare was always an odd case with odd facts, and serious scrutiny of deal protection measures and protection of shareholder voting rights still seems alive in Delaware. The independence scrutiny in Beam and Oracle is highly fact-specific; the basic legal standard remains the same. Disney did create the potential for wider use of a new good faith standard in executive compensation cases and other areas, even though it did not give much guidance as to what that standard might entail.

Of most interest at the federal level is the ongoing dispute over shareholder access to the corporate proxy to nominate board candidates. Perhaps the most interesting and potentially important post-SOX development at any level of government was the SEC's proposed new rule giving shareholders the right to use the corporate proxy to nominate directors candidates under carefully limited circumstances. This proposal could cut more deeply to the heart of the balance of power between directors and shareholders than anything else in the SOX flurry of reform. However, the post-SOX resurgence of normal interest group politics seems to have killed this proposal.

I don't believe that the SEC's proposal was the best way to go on the shareholder access issue. Better would be to allow shareholders to propose bylaws granting shareholders proxy access to nominate directors under the conditions laid out in the bylaws. This would allow greater flexibility and experimentation than the one-size-fitsall SEC proposed rule. However, a bylaw-based approach requires favorable action at both the state and federal level. At the state level, state courts must recognize as valid shareholder bylaws that grant proxy access under specified conditions. At the federal level, the SEC must not allow companies to exclude shareholder proposals that propose such bylaws. 
The validity of shareholder bylaws that may impinge upon board authority is an open and vexed question under Delaware law. The type of bylaw that has received the most scholarly attention is bylaws limiting the power of boards to adopt or use poison pills. Proxy access bylaws are a newer innovation, and so far have received less analysis. In a recent article I analyzed both types of bylaws under Delaware law (the analysis would be similar but not identical under the law of most other states). I found that proxy access bylaws are likely to be held as valid under Delaware law; poison pill bylaws are more questionable. We shall see what happens if and when the issue ever actually reaches a Delaware court. Pro-shareholder-power scholar Lucian Bebchuk recently tried to force the issue by bringing a case in Delaware, but the Chancery court held that the case was not ripe for decision.

Part of the reason that this important issue has not yet made its way to the state courts is that shareholders have not been able to get the issue on the ballot without enduring the expense of soliciting proxies on their own. That is because of the way the SEC has interpreted one of its rules implementing Rule 14a-8. Rule 14a-8 allows shareholders who have met relatively minimal procedural requirements to use the corporate proxy material to distribute proposals for other shareholders to vote on. However, the rule contains a variety of exclusions which companies can use to refuse to include a shareholder proposal in their proxies. One of these exclusions is 14a-8(i)(8), which allows companies to exclude a proposal if it "relates to an election for membership on the company's board of directors or analogous governing body."

This exclusion has a broad and a narrow interpretation. Under the broad interpretation, all proposals which regulate or affect board elections may be excluded. Under the narrow interpretation, only proposals which relate to one particular election, e.g. using the Rule to propose a slate of directors, may be excluded. Under the broad interpretation, proxy access bylaw proposals are excludable; under the narrow interpretation they are not. The SEC has vacillated over time in how it interpreted this exclusion. Initially it interpreted the exclusion narrowly. For the last fifteen years or so it has usually interpreted it broadly. Recently, in the shadow of the proxy access rule proposal, the staff suggested returning to the narrow interpretation in a no action letter for a proposal by Disney shareholders. However, the Commission reverted to the broad interpretation - another sign of the post-SOX resurgence of manager political influence.

When AIG excluded a proxy access proposal by the AFSCME union pension plan, the union went to court to try to push for the narrow interpretation. The union lost at the district court level, but won with the Second Circuit. The circuit court noted the ambiguity of the exclusion's text, making the nice albeit rather fine point that the "an" in front of "election" in the exclusion suggests reference to one particular election. The court then noted the muddled history of SEC interpretation of the exclusion. It decided to side with the SEC's earlier interpretation, which occurred closer in time to the initial adoption of the exclusion.

I am quite sympathetic to the court's opinion, although it is not clear that the opinion gives appropriate deference to the SEC's current stance, thereby allowing the 
agency flexibility to adapt to changing circumstances. I suspect the court was in part influenced by a covert policy preference for the narrow interpretation. Our analysis of the politics underlying this area suggests a policy-based reason in favor of the decision beyond simply arguing that this is the better substantive outcome. Managers and their allies are likely to be able to organize better to influence the SEC. This suggests that where in doubt the court should interpret the rule against the interests of managers. If that interpretation is not in fact good policy, there is a good chance that managers will be able to organize effectively to overturn the decision. Indeed, that may well happen in this case, as we shall see. If instead the court were to follow a pro-manager interpretation, it is much less likely that shareholder activists will be able to successfully lobby the SEC to overturn the decision even if the public interest favors their preferred rule.

This argument for how the federal courts should approach the SEC's rules dovetails with our general analysis of the interaction between federal and state regulators and between informed and uninformed regulators. The federal courts do not know much about securities and corporate law - they do not face related cases very often. They are thus uninformed, but for the very same reason also less likely to be biased in favor of managers or any other corporate constituency group. By interpreting rules such as this one in a pro-shareholder way, the courts help counteract managerialist bias while still allowing the more informed SEC to change the rule if it believes strongly enough that the court's decision is wrong.

The SEC is considering a proposed rule change in response to AFSCME v. AIG. As of this writing they have not yet published their proposal. I assume that it will embody the broad interpretation of the existing exclusion that the SEC has been following. It remains an open question whether or not shareholder activists will be able to muster strong enough opposition to keep the $A I G$ status quo in place. If they do succeed, it will be a nice example of our complex system of regulating corporations at work, with its mix of federal and state, informed and uninformed regulators interacting in myriad ways. If corporate managers succeed in getting their way and overturning the court's decision, the system will look less good, although even then it would be far from clear that any other system would do any better. The greater lobbying power of managers and corporate lawyers will be a systematic problem for any form of legal regulation of corporations.

VI. Conclusion 